\title{
The Feeding Value of Corn Distillers Solubles for Lactating Dairy Cows ${ }^{\mathbf{1}}$
}

\author{
A. K. Sasikala-Appukuttan, ${ }^{\star 2}$ D. J. Schingoethe, ${ }^{\star 3}$ A. R. Hippen, ${ }^{\star}$ K. F. Kalscheur, ${ }^{\star}$ \\ K. Karges, $†$ and M. L. Gibson† \\ *Dairy Science Department, South Dakota State University, Brookings 57007-0647 \\ †Poet Nutrition, Sioux Falls, SD 57104
}

\begin{abstract}
Fifteen Holstein cows (10 multiparous and 5 primiparous) in early to mid lactation (79.3 $\pm 9.2 \mathrm{~d}$ in milk) were used in a multiple $5 \times 5$ Latin square design with 4 -wk periods to evaluate and compare the use of condensed corn distillers solubles (CCDS) and dried distillers grains with solubles (DDGS) in the total mixed ration. The forage portion of the diets was kept constant at $27.5 \%$ corn silage and $27.5 \%$ alfalfa hay (dry matter basis). Diets were 1) $0 \%$ distillers grains products (control); 2) 18.5\% DDGS; 3) 10\% CCDS; 4) 20\% CCDS; and 5) a combination diet of $18.5 \%$ DDGS with $10 \%$ CCDS. Diets 2 and 3 contained 2\% fat from DDGS or CCDS, whereas diet 4 contained $4 \%$ fat from CCDS and diet 5 contained $4 \%$ fat from the blend of DDGS and CCDS. The diets were balanced to provide $17 \%$ crude protein with variation in acid detergent fiber, neutral detergent fiber, and fat concentration. Dry matter intake (21.5 $\mathrm{kg} / \mathrm{d}$ ) was similar for all diets. Milk yield (33.8, 36.2, $35.5,36.0$, and $36.0 \mathrm{~kg} / \mathrm{d}$ ) tended to be greater for diets 2 to 5 than for diet 1 , whereas yields of fat $(1.04 \mathrm{~kg} / \mathrm{d})$, protein $(1.02 \mathrm{~kg} / \mathrm{d})$, fat percentage $(2.94)$, and protein percentage (2.98) were similar for all diets. Energycorrected milk $(32.2 \mathrm{~kg} / \mathrm{d})$ and feed efficiency $(1.58 \mathrm{~kg}$ of energy-corrected milk/kg of dry matter intake) were similar for all diets. Milk urea nitrogen (15.0, 10.9, 11.1, 11.0 , and $11.4 \mathrm{mg} / \mathrm{dL}$ ) as well as blood urea nitrogen $(15.6,12.5,14.6,13.8$, and $14.2 \mathrm{mg} / \mathrm{dL})$ were decreased in diets 2 to 5 compared with diet 1 . Milk concentrations of long-chain fatty acids as well as polyunsaturated fatty acids were greater and medium-chain fatty acid concentrations were lower for diets 2 to 5 compared with diet 1 . Concentrations of cis-9, trans-11 conjugated linoleic acid (CLA; 0.33, 0.68, 0.51, 0.85, and $1.07 \mathrm{~g} / 100$
\end{abstract}

\footnotetext{
Received April 1, 2007.

Accepted September 11, 2007.

${ }^{1}$ Published with the approval of the director of the South Dakota Agricultural Experiment Station as Publication Number 3594 of the Journal Series.

${ }^{2}$ Current address: Department of Animal and Avian Sciences, University of Maryland, College Park, MD 20742-2311.

${ }^{3}$ Corresponding author: david.schingoethe@sdstate.edu
}

g of fatty acids) as well as trans-10, cis-12 CLA $(<0.01$, $0.01,<0.01,0.02$, and $0.02 \mathrm{~g} / 100 \mathrm{~g}$ of fatty acids) were greater for diets 2 to 5 compared with diet 1 . Molar proportions of ruminal acetate decreased and propionate increased for diets 2 to 5 compared with diet 1 . The results showed that CCDS is as effective as DDGS in replacing soybean meal and corn grain in the total mixed ration.

Key words: condensed corn distillers solubles, dried distillers grains with solubles, dairy cattle

\section{INTRODUCTION}

The production of ethanol from grains yields various byproducts and coproducts that are recovered and fed to cattle (Schingoethe, 2007). Distillers dried grains with solubles (DDGS) is one of the byproducts and is made by blending distillers solubles (sometimes referred to as "syrup" or "thin stillage") with distillers grains (DG). The use of DDGS as a protein supplement in lactating cows is well recognized (Schingoethe, 2007) even though there may be value in separating all or some of the solubles from DG for feeding directly to dairy cattle. This separation of solubles could alleviate some of the problems of inconsistency in DDGS when variable amounts of solubles are added back to DG because solubles are greater in $\mathrm{P}(\sim 1.35$ vs. $\sim 0.4 \% \mathrm{P}$ in DG) and in fat ( 22 vs. 9\% fat in DG).

Limited research has evaluated the feeding of distillers solubles separately from distillers grains. Da Cruz et al. (2005) demonstrated that feeding up to $10 \%$ of ration DM as condensed corn distillers solubles (CCDS) can increase milk production although there was a slight decrease in milk fat percentage. Udedibie and Chase (1988) reported that feeding 1.70 or $3.40 \mathrm{~kg} \mathrm{DM}$ of CCDS per day to lactating cows satisfactorily replaced parts of soybean meal and corn in the ration and maintained milk yield. In Finland, Huhtanen and Miettinen (1992), using wet distillers solubles that contained more protein and less fat than the solubles routinely available in the United States, also observed increased milk production. Da Cruz et al. (2005) reported the composition of major fatty acids in milk fat when 
cows were fed CCDS but did not report concentrations of fatty acids such as cis-9, trans-11 conjugated linoleic acid (CLA), and trans-10, cis-12 CLA. However, feeding CCDS may increase the concentration of CLA in milk because CCDS contains about $20 \%$ fat in a form that may alter ruminal metabolism.

The objectives of this experiment were to evaluate the feeding of CCDS to lactating cows, determine the optimal amount to include in diets, and determine the feasibility of feeding CCDS with or without DDGS.

\section{MATERIALS AND METHODS}

Fifteen Holstein cows (10 multiparous and 5 primiparous) in mid lactation, averaging $79( \pm 9)$ DIM, were used to evaluate and compare the feeding of CCDS at 2 concentrations and DDGS at 1 level of inclusion along with a mixed diet that included both CCDS and DDGS. Cows were blocked into 3 squares of 5 cows each based upon parity, production, and DIM, and within blocks were assigned to 1 of the 5 experimental diets in a mutiple $5 \times 5$ Latin square design trial. Treatment diets were randomly assigned after blocking. Cows were housed in a free-stall barn and fed diets in a TMR with a Calan Broadbent feeder door and box system (American Calan Inc., Northwood, NH). Cows were started under the Calan feeding system $10 \mathrm{~d}$ before the start of the experiment to adapt to the feeding system. Each experimental period consisted of $4 \mathrm{wk}$, with the initial 2 wk for adaptation and wk 3 and 4 for data collection.

The 5 treatments diets were: 1) control at $0 \%$ distillers grains products; 2) 18.5\% DDGS; 3) 10\% CCDS; 4) $20 \%$ CCDS; and 5) a mixed diet of $18.5 \%$ DDGS and $10 \%$ CCDS. Diets 2 and 3 contained $2 \%$ fat from DDGS or CCDS, respectively; diet 4 contained $4 \%$ fat from CCDS, and diet 5 contained $4 \%$ fat from distillers products (2\% from each of DDGS and CCDS). Diets (Table 1) were formulated to contain $17 \% \mathrm{CP}$, using corn grain and soybean meal as the base of the concentrate mix, and distillers byproducts replacing a portion of these ingredients in the treatment diets. All diets contained $27.5 \%$ alfalfa hay and $27.5 \%$ corn silage. Forages were premixed for all diets in a mixer wagon (1999 NDE 500, Westside Implement, Clark, SD). Concentrate mix and CCDS were added to the Calan Data Ranger (American Calan Inc.) after addition of premixed forages. The DDGS were mixed into the concentrate mix at the South Dakota State University feed mill (Brookings). Condensed corn distillers solubles were transported from the ethanol plant once a month and stored in a tank with a capacity of approximately $1,100 \mathrm{~kg}$. Condensed corn distillers solubles were agitated daily by circulation for about $0.5 \mathrm{~h}$ before incorporating into the TMR.
Table 1. Ingredient composition of $\operatorname{diets}^{1}$

\begin{tabular}{|c|c|c|c|c|c|}
\hline \multirow[b]{2}{*}{ Item } & \multicolumn{5}{|c|}{ Diet } \\
\hline & Control & $\begin{array}{l}18.5 \% \\
\text { DDGS }\end{array}$ & $\begin{array}{c}10 \% \\
\text { CCDS }\end{array}$ & $\begin{array}{c}20 \% \\
\text { CCDS }\end{array}$ & $\begin{array}{l}18.5 \% \\
\text { DDGS } \\
+10 \% \\
\text { CCDS }\end{array}$ \\
\hline & & $-(c$ & of $\mathrm{DM})$ & & \\
\hline Corn silage & 27.5 & 27.5 & 27.5 & 27.5 & 27.5 \\
\hline Alfalfa hay & 27.5 & 27.5 & 27.5 & 27.5 & 27.5 \\
\hline Corn, ground, shelled & 32.5 & 23.5 & 24.7 & 16.9 & 14.8 \\
\hline Soybean meal, $44 \% \mathrm{CP}$ & 10.4 & 1.1 & 8.5 & 6.4 & - \\
\hline DDGS & - & 18.5 & - & - & 18.5 \\
\hline CCDS & - & - & 10 & 20 & 10 \\
\hline Trace mineralized salt ${ }^{2}$ & 0.5 & 0.5 & 0.5 & 0.5 & 0.5 \\
\hline Magnesium oxide & 0.16 & 0.13 & 0.06 & - & 0.01 \\
\hline Vitamin premix ${ }^{3}$ & 0.21 & 0.21 & 0.21 & 0.21 & 0.21 \\
\hline Vitamin E premix ${ }^{4}$ & 0.04 & 0.04 & 0.04 & 0.04 & 0.04 \\
\hline Limestone & 0.62 & 0.82 & 0.90 & 0.88 & 0.85 \\
\hline Dicalcium phosphate & 0.44 & 0.09 & - & - & - \\
\hline Zinpro $^{5}$ & 0.09 & 0.09 & 0.09 & 0.09 & 0.09 \\
\hline
\end{tabular}

${ }^{1}$ Diets were 1) $0 \%$ distillers grains products (control); 2) $18.5 \%$ dried distillers grains with solubles (DDGS); 3) $10 \%$ condensed corn distillers solubles (CCDS); 4) 20\% CCDS; and 5) a combination diet of $18.5 \%$ DDGS with $10 \%$ CCDS.

${ }^{2}$ Trace mineralized salt: $36.6 \% \mathrm{Na}, 58.79 \% \mathrm{Cl}, 0.29 \mathrm{mg} / \mathrm{kg} \mathrm{Fe}, 0.58$ $\mathrm{mg} / \mathrm{kg} \mathrm{Mn}, 0.02 \mathrm{mg} / \mathrm{kg} \mathrm{Cu}, 0.01 \mathrm{mg} / \mathrm{kg} \mathrm{I}$, and $0.80 \mathrm{mg} / \mathrm{kg} \mathrm{Zn}$.

${ }^{3}$ Content of vitamin premix: $2,500,000 \mathrm{IU} / \mathrm{kg}$ vitamin A, 400,000 IU/kg vitamin D and 1,000 IU/kg vitamin $\mathrm{E}$.

${ }^{4}$ Content of vitamin E premix: 44,000 IU/kg vitamin $\mathrm{E}$.

${ }^{5} 125 \mathrm{mg} / \mathrm{kg} \mathrm{Cu}, 200 \mathrm{mg} / \mathrm{kg} \mathrm{Mn}$, and $360 \mathrm{mg} / \mathrm{kg} \mathrm{Zn;} \mathrm{Zinpro} \mathrm{Corp.,}$ Eden Prairie, MN.

Diets were fed in amounts to allow for ad libitum consumption.

Feed intake for individual cows was measured daily with the Calan Broadbent feeder door system and Data Ranger. On d 7 of each week of the study, samples of corn silage, alfalfa hay, each concentrate mix, DDGS, CCDS, and each diet were collected and stored at $-20^{\circ} \mathrm{C}$ until analysis. Dry matter concentrations were determined weekly on an aliquot of CCDS, corn silage, alfalfa hay, and diet by drying at $105^{\circ} \mathrm{C}$ for $48 \mathrm{~h}$, and "as-fed" amounts of ingredients were adjusted to ensure proper inclusion of CCDS and corn silage. The weekly diet DM were used to calculate DMI.

Composites were made by period for all feeds sampled. Composites were dried for $48 \mathrm{~h}$ at $55^{\circ} \mathrm{C}$ in a Despatch oven (style V-23, Despatch Oven Co., Minneapolis, MN), ground to a 4-mm particle size (Wiley mill, model 3; Arthur H. Thomas Co., Philadelphia, PA), and to a 1-mm particle size using an ultracentrifuge mill (Brinkman Instruments Co., Westbury, NY). All feed samples were analyzed for true DM, ash, NDF, ADF, lignin, ether extract, and CP. True DM was determined by taking approximately $1 \mathrm{~g}$ of ground sample and drying at $105^{\circ} \mathrm{C}$ for $24 \mathrm{~h}$ for correction to $100 \% \mathrm{DM}$. Ash was determined by combusting samples in a muffle furnace at $450^{\circ} \mathrm{C}$ for $8 \mathrm{~h}$ (Undersander et al., 1993). Con- 
centrations of $\mathrm{NDF}, \mathrm{ADF}$, and lignin were determined using the Ankom fiber analysis system (Ankom Technology Corp., Fairport, NY). The method for NDF was based upon procedures described by Van Soest et al. (1991), Robertson and Van Soest (1981) for ADF, and Lowry et al. (1994) for lignin. Crude protein was determined using method 920.87 of AOAC (2002). Ether extracts were analyzed using the Goldfish method (method 920.85; AOAC, 2002). Feed fatty acids were extracted (AbuGhazaleh et al., 2002) and prepared as butyl esters for analysis using gas chromatography (model 6890, Hewlett-Packard, Palo Alto, CA). The samples were analyzed using a flame-ionization detector with the injector port at a temperature of $2300 \mathrm{C}$ and a split ratio of 100:1. The length of the column was 100 $\mathrm{m}$ with an inside diameter of $0.25 \mathrm{~mm}$ (Supelco 2560, Supelco Inc., Bellefonte, PA). The flow rate was $2.0 \mathrm{~mL} /$ min of helium. Detector and column were maintained at 250 and $230^{\circ} \mathrm{C}$ (AbuGhazaleh et al., 2002).

Cows were milked 3 times a day at 600,1400, and $2100 \mathrm{~h}$, and a record of daily milk production was kept. Milk samples were collected at all 3 milking times for 2 consecutive days during wk 3 and 4 of each period. Composites of milk samples were made by day on a percentage by weight basis and sent to Heart of American DHI Laboratory (Manhattan, KS) for analysis. Milk components such as fat, protein, and lactose were analyzed by near infrared spectroscopy (method 972.16; AOAC, 2002) using a Bentley 2000 Infrared Milk Analyzer (Bentley Instruments, Chaska, MN), whereas MUN concentration was determined using chemical methods based on a modified Berthelot reaction (ChemSpec 150 Analyzer, Bentley Instruments; Chaney and Marbach, 1962). Somatic cell counts were determined with a flow cytometer laser (Somacount 500, Bentley Instruments). Energy-corrected milk was determined using the equation: $[(0.327 \times \mathrm{kg}$ of milk $)+(12.95 \times \mathrm{kg}$ of fat $)+(7.2 \times \mathrm{kg}$ of protein)] (Orth, 1992). Additional composites of wk 4 milk samples were made for each cow and period and prepared for milk fatty acid composition analysis using an adaptation (AbuGhazaleh et al., 2002) to the method of Sukhija and Palmquist (1988), modified to form butyl esters. The samples were then analyzed by gas chromatography (model 6890, Hewlett Packard) as described for feed fatty acids.

Cows were weighed $3 \mathrm{~d}$ before the beginning of the trial and on the last $3 \mathrm{~d}$ of each period. Body condition scores were recorded independently by 3 individuals at the start of the trial and at the end of each period. Body condition scores were made using a scale of 1 to 5 , where 5 represents obese and 5 represents emaciated (Wildman et al., 1982).

Samples of rumen fluid were collected on $2 \mathrm{~d}$ in wk 4 of each period, approximately 2 to $3 \mathrm{~h}$ postfeeding by applying vacuum pressure to a hand-operated esophageal tube with a suction strainer. The first $250 \mathrm{~mL}$ of rumen fluid was discarded before sample collection to minimize contamination with saliva. Ten-milliliter aliquots of rumen fluid samples were mixed with $2 \mathrm{~mL}$ of $25 \%$ (wt/vol) meta-phosphoric acid and placed immediately into storage tubes. The rumen fluid samples were stored at $-20^{\circ} \mathrm{C}$ until analysis for ammonia nitrogen concentration (Chaney and Marbach, 1962), and VFA (Ottenstein and Bartley, 1971) using gas chromatography (model 6890, Hewlett-Packard) with a flame-ionization detector. The injector port was at a temperature of $250^{\circ} \mathrm{C}$ with a split ratio of $100: 1$, a 15 -m-long column, and a diameter of $0.25 \mathrm{~mm}$ (Nukal, Supelco Inc.). Flow rate was $1.3 \mathrm{~mL} / \mathrm{min}$ of helium. Detector and column were maintained at 225 and $130^{\circ} \mathrm{C}$, respectively.

Blood was sampled from a coccygeal vessel approximately $3 \mathrm{~h}$ after feeding on the last day of wk 4 of each period into vacuum tubes containing heparin (Becton Dickinson Vacutainer Systems, Rutherford, NJ). The samples were immediately placed on ice and transported to the laboratory where they were centrifuged $(500 \times g)$ and plasma separated. Plasma samples were stored at $-20^{\circ} \mathrm{C}$ for urea $\mathrm{N}$ determination (Stanbio Urea Nitrogen kit, Stanbio Laboratory, Boerne, TX; diacetylmonoxime methodology) based on procedures of Feron (1939) and Wybenga et al. (1971).

Period means for all production measurements were calculated and used for statistical analysis. The data were analyzed using the MIXED procedure (SAS Institute, 1999). The model used cow as the experimental unit and cow (parity) as the random effect. The model was:

$\mathrm{Y}=$ Treatment + Parity + Period + Treatment $\times$ Parity

The treatment $\times$ parity interaction was deemed insignificant because all $P$-values were greater than 0.20 , so it was removed from the model for all variables tested. Significance was declared at $P<0.05$, and tendency was indicated at $P<0.10$. Preplanned orthogonal contrasts were based upon experimental objectives: 1) control vs. all other diets, 2) DDGS diet vs. $10 \%$ CCDS, 3) $10 \%$ CCDS vs. $20 \%$ CCDS, and 4) $20 \%$ CCDS vs. a mixed diet of DDGS and 10\% CCDS.

\section{RESULTS AND DISCUSSION}

\section{Nutrient Content of Diets}

The chemical composition of diet ingredients and TMR are described in Table 2. Calculations of items such as microbial flow, lysine composition, RUP, and RDP based on the NRC model (2001) were not made 
Table 2. Chemical composition of alfalfa hay (AH), corn silage (CS), condensed corn distillers solubles (CCDS), concentrate mixes, and TMR for control, 18.5\% dried distillers grains with solubles (DDGS), 10\% CCDS, 20\% CCDS, and 18.5\% DDGS with 10\% CCDS treatment diets

\begin{tabular}{|c|c|c|c|c|c|c|c|c|c|c|c|c|c|}
\hline \multirow[b]{2}{*}{ Item } & \multirow[b]{2}{*}{$\mathrm{AH}$} & \multirow[b]{2}{*}{ CS } & \multirow[b]{2}{*}{ CCDS } & \multicolumn{5}{|c|}{ Concentrate mixes ${ }^{1}$} & \multicolumn{5}{|c|}{$\mathrm{TMR}^{2}$} \\
\hline & & & & Control & $\begin{array}{l}18.5 \% \\
\text { DDGS }\end{array}$ & $\begin{array}{l}10 \% \\
\text { CCDS }\end{array}$ & $\begin{array}{l}20 \% \\
\text { CCDS }\end{array}$ & $\begin{array}{l}18.5 \% \text { DDGS } \\
+10 \% \text { CCDS }\end{array}$ & Control & $\begin{array}{l}18.5 \% \\
\text { DDGS }^{3}\end{array}$ & $\begin{array}{c}10 \% \\
\text { CCDS }\end{array}$ & $\begin{array}{l}20 \% \\
\text { CCDS }\end{array}$ & $\begin{array}{l}18.5 \% \text { DDGS } \\
+10 \% \text { CCDS }\end{array}$ \\
\hline DM, \% & 86.5 & 29.9 & 26.8 & 89.9 & 90.4 & 88.8 & 88.6 & 89.6 & 53.3 & 54.7 & 46.3 & 40.4 & 47.3 \\
\hline $\mathrm{CP}$ & 17.3 & 8.7 & 19.5 & 18.7 & 18.8 & 20.3 & 21.4 & 20.8 & 15.9 & 15.9 & 16.2 & 16.4 & 16.4 \\
\hline $\mathrm{EE}^{4}$ & 1.8 & 3.4 & 21.3 & 1.9 & 5.6 & 1.8 & 1.9 & 7.1 & 2.5 & 4.1 & 4.2 & 6.2 & 6.1 \\
\hline $\mathrm{ADF}$ & 35.9 & 30.2 & 3.1 & 3.9 & 4.8 & 4.0 & 4.1 & 5.4 & 18.9 & 19.4 & 19.1 & 19.1 & 19.6 \\
\hline NDF & 49.5 & 52.2 & 5.3 & 10.7 & 17.5 & 11.5 & 11.7 & 19.8 & 30.8 & 33.8 & 30.9 & 30.2 & 33.6 \\
\hline Lignin & 9.1 & 2.5 & - & 0.5 & 0.6 & 0.6 & 0.6 & 0.7 & 3.4 & 3.5 & 3.4 & 3.4 & 3.5 \\
\hline $\mathrm{NE}_{\mathrm{L}}^{5}$ & - & - & - & - & - & - & - & - & 1.56 & 1.58 & 1.60 & 1.65 & 1.62 \\
\hline Ash & 7.7 & 4.6 & 12.1 & 8.5 & 7.2 & 8.8 & 11.3 & 7.9 & 7.2 & 7.3 & 8.0 & 8.7 & 7.9 \\
\hline $\mathrm{Ca}$ & - & - & 0.15 & - & - & - & - & - & 0.87 & 0.84 & 0.81 & 0.87 & 0.86 \\
\hline $\mathrm{P}$ & - & - & 1.53 & - & - & - & - & - & 0.36 & 0.38 & 0.44 & 0.57 & 0.48 \\
\hline $\mathrm{pH}$ & - & - & 4.2 & - & - & - & - & - & - & - & - & - & - \\
\hline
\end{tabular}

${ }^{1}$ Concentrate mixes: DDGS was included in concentrate mix, whereas CCDS was not included; CCDS was added when the TMR mix was added to the Data Ranger.

${ }^{2}$ Based on a combination of direct analyses of TMR and "calculated TMR" from analyses of ingredients.

${ }^{3}$ Distillers grains with solubles was $32.9 \% \mathrm{CP}, 9.7 \% \mathrm{EE}, 15.5 \% \mathrm{ADF}, 36.7 \% \mathrm{NDF}, 3.9 \%$ lignin, $4.5 \%$ ash, $0.05 \% \mathrm{Ca}$, and $0.86 \% \mathrm{P}$.

${ }^{4} \mathrm{EE}=$ ether extract.

${ }^{5} \mathrm{Mcal} / \mathrm{kg}$; estimated from NRC, 2001.

because of insufficient data on some diet components, especially CCDS. The DM percentage of CCDS (26.8\%) was slightly lower than the $30 \%$ estimated before the start of the experiment and the $30.7 \%$ of DM obtained by Gilbery et al. (2006). The ether extract content of CCDS was similar to those in some studies (Da Cruz et al., 2005; Gilbery et al., 2006), but less than observed in other studies (Udedibie and Chase, 1988; Gilbery et al., 2006). Consequently, when CCDS was added to the diet, the DM content of the diets decreased to $<50 \%$ while ether extract increased. The diets contained slightly less CP than originally estimated (17\%), primarily because of less protein in the alfalfa than calculated. The P concentrations in the 20\% CCDS diet and the mixed diet (DDGS plus CCDS) were greater than the desired $0.4 \%$ because of the high $\mathrm{P}$ content (1.53\%) in CCDS.

The fatty acid composition of the CCDS, concentrate mixes, and TMR are in Table 3. The CCDS was high in C14:0, C16:0, C18:1, and C18:2, which is typical of corn-product fatty acids, although it was higher in C14:0 than anticipated. The inclusion of $2 \%$ fat from DDGS increased the proportion of C18:2. As expected, the total fatty acid content of diets increased when $2 \%$ fat was included in the form of $18.5 \%$ DDGS or $10 \%$ CCDS and $4 \%$ fat included as $20 \%$ CCDS or the mixed diet.

\section{DMI and Lactational Response}

Dry matter intakes (Table 4) were similar for all diets. Lahr et al. (1983) reported that DMI declined linearly as the DM content of TMR declined from 78 to $40 \%$. Da Cruz et al. (2005) observed a similar type of response for DMI when feeding CCDS, whereas Schingoethe et al. (1999) reported that DMI was lower when cows were fed wet corn distillers grains in diets that were $45 \%$ DM. In an experiment conducted by Huhtanen and Miettinen (1992), DMI by dairy cows increased linearly as wet distillers solubles increased in the diet from 1 to $3 \mathrm{~kg}$ of $\mathrm{DM} / \mathrm{d}$.

A trend $(P=0.08)$ toward increased milk production was observed (Table 4) when cows were fed distillers diets compared with the control diet. The slightly greater energy density in distillers diets (estimated $\mathrm{NE}_{\mathrm{L}} 1.58$ to $1.65 \mathrm{Mcal} / \mathrm{kg}$ ), primarily because those diets contained more fat compared with the control diet (1.56 $\mathrm{Mcal} / \mathrm{kg}$ ), may have contributed to some of this increased production. Milk production was similar for cows fed the DDGS, low CCDS (10\%), high CCDS (20\%) diets, and the mixed diet. Da Cruz et al. (2005) also observed increased milk production for cows fed CCDS diets compared with a control diet even though there was no difference between diets containing 5 and $10 \%$ of DM as CCDS. Huhtanen and Miettinen (1992) observed a linear increase in milk production by increasing the level of wet distillers solubles in the diet. Anderson et al. (2006) and Kleinschmit et al. (2006) observed increased milk production for DDGS diets compared with the control.

Diets containing extra fat sometimes increase milk production (Palmquist and Jenkins, 1980; Maiga et al., 1995) although in the present study, cows fed $4 \%$ added fat from $20 \%$ CCDS or from the mixed diet $(18.5 \%$ 
Table 3. Fatty acid composition of alfalfa hay (AH), corn silage (CS), condensed corn distillers solubles (CCDS), concentrate mixes, and TMR for control, $18.5 \%$ dried distillers grains with solubles (DDGS), 10\% CCDS, $20 \%$ CCDS, and 18.5\% DDGS with $10 \%$ CCDS treatment diets

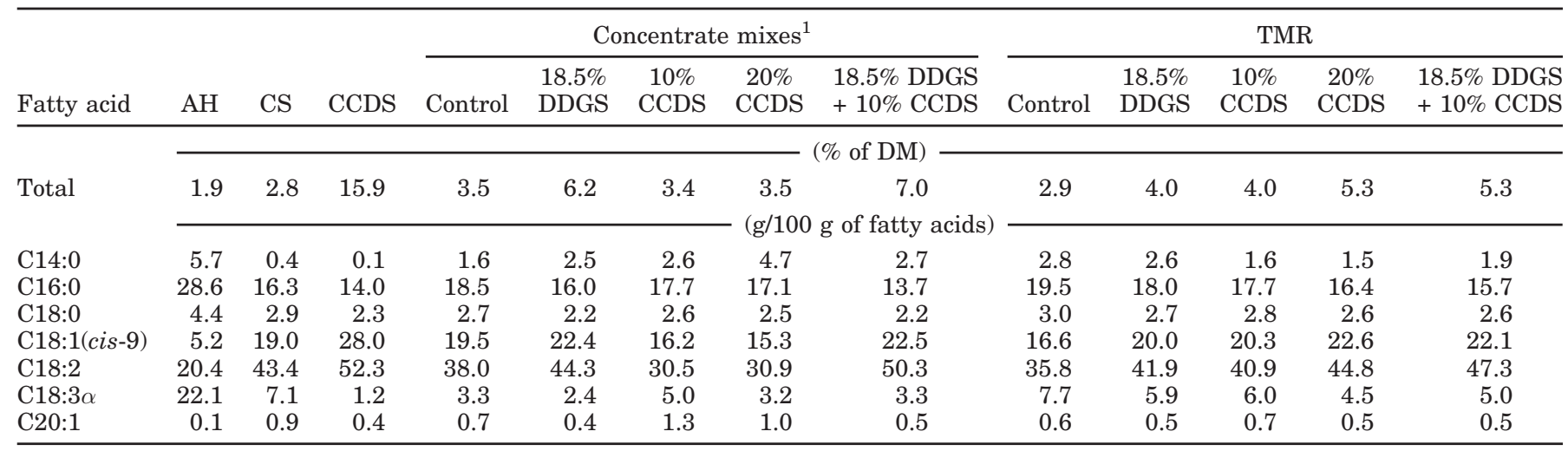

DDGS with $10 \%$ CCDS) did not differ significantly from those fed diets with $2 \%$ added fat (18.5\% DDGS; $10 \%$ CCDS). Feeding additional fat as 10 or $20 \%$ wet or dried distillers grains with solubles (Anderson et al., 2006) increased milk production with no change in milk fat concentration. However, when Leonardi et al. (2005) fed DDGS or corn oil in diets containing insufficient amounts of forage fiber (17.4\% forage NDF; NRC, 2001), milk production still increased but milk fat content was modestly decreased. Energy-corrected milk yield and feed efficiency expressed as kilograms of ECM/kilogram of DMI were similar for all diets.

The milk fat content and milk fat yield from cows did not show any significant differences between the TMR diets. Surprisingly, the milk fat percentage for cows fed the control diet $(3.04 \%)$ was lower than anticipated, with the milk fat percentage for all distillers diets being $<3 \%$. Although there was no explanation for this, it may have been due to high ambient temperatures during this experiment. This study was conducted from June through September, which may have depressed feed intake and milk production, and contributed to low milk fat concentration. Reduced particle size or inadequate amounts of forage fiber can also contribute to low milk fat percentages (Grant, 1997; Leonardi et al., 2005), but did not appear to be factors in this experiment. Da Cruz et al. (2005) observed decreased milk fat concentration coupled with increased protein and lactose production when cows were fed CCDS. Udedibie and Chase (1988) observed no differences in milk fat percentages

Table 4. Dry matter intake, milk yield and composition, efficiency calculations, and body characteristics for cows fed control and diets containing 18.5\% dried distillers grains with solubles (DDGS), 10\% condensed corn distillers solubles (CCDS), 20\% CCDS, and a mixed diet containing 18.5\% DDGS with 10\% CCDS

\begin{tabular}{|c|c|c|c|c|c|c|c|c|c|c|}
\hline \multirow[b]{3}{*}{ Item } & \multicolumn{5}{|c|}{ Diet } & \multirow[b]{3}{*}{ SEM } & \multirow{2}{*}{\multicolumn{4}{|c|}{ Contrast $^{1}$ ( $P$-value $)$}} \\
\hline & & $18.5 \%$ & $10 \%$ & $20 \%$ & $18.5 \%$ DDGS & & & & & \\
\hline & Control & DDGS & CCDS & CCDS & $+10 \% \mathrm{CCDS}$ & & A & B & $\mathrm{C}$ & D \\
\hline DMI, kg/d & 21.3 & 22.0 & 20.8 & 21.3 & 21.9 & 1.53 & 0.83 & 0.25 & 0.66 & 0.55 \\
\hline Milk yield, kg/d & 33.8 & 36.2 & 35.5 & 36.0 & 36.0 & 1.86 & 0.08 & 0.61 & 0.73 & 0.97 \\
\hline Fat, \% & 3.04 & 2.87 & 2.96 & 2.96 & 2.88 & 0.10 & 0.20 & 0.45 & 0.96 & 0.49 \\
\hline Fat, kg/d & 1.03 & 1.02 & 1.04 & 1.06 & 1.04 & 0.06 & 0.74 & 0.75 & 0.75 & 0.69 \\
\hline Protein, \% & 2.92 & 2.88 & 2.98 & 2.88 & 2.90 & 0.05 & 0.17 & 0.95 & 0.95 & 0.48 \\
\hline Protein, kg/d & 0.99 & 1.03 & 1.01 & 1.03 & 1.04 & 0.05 & 0.23 & 0.61 & 0.65 & 0.81 \\
\hline Lactose, \% & 4.84 & 4.83 & 4.80 & 4.81 & 4.80 & 0.03 & 0.26 & 0.30 & 0.66 & 0.69 \\
\hline Lactose, kg/d & 1.64 & 1.75 & 1.71 & 1.73 & 1.73 & 0.09 & 0.13 & 0.59 & 0.76 & 0.97 \\
\hline MUN, mg/dL & 14.99 & 10.91 & 11.05 & 11.04 & 11.42 & 1.31 & $<0.01$ & 0.94 & 0.99 & 0.84 \\
\hline SCC, $10^{3} / \mathrm{mL}$ & 94.9 & 101.2 & 100.7 & 93.1 & 213.1 & 0.45 & 0.46 & 0.99 & 0.89 & 0.03 \\
\hline ECM, kg/d & 31.0 & 32.4 & 32.3 & 32.8 & 32.7 & 1.67 & 0.19 & 0.93 & 0.73 & 0.96 \\
\hline $\mathrm{FE}^{2}$ & 1.55 & 1.60 & 1.62 & 1.59 & 1.55 & 0.12 & 0.51 & 0.83 & 0.69 & 0.72 \\
\hline BW, kg & 648.4 & 654.4 & 656.6 & 657.1 & 661.2 & 16.6 & 0.09 & 0.75 & 0.87 & 0.61 \\
\hline BCS & 3.38 & 3.29 & 3.43 & 3.44 & 3.41 & 0.06 & 0.85 & 0.04 & 0.84 & 0.67 \\
\hline BUN, mg/dL & 15.55 & 12.49 & 14.62 & 13.83 & 14.22 & 0.82 & 0.05 & 0.06 & 0.49 & 0.73 \\
\hline
\end{tabular}

${ }^{1}$ Contrast: $\mathrm{A}=$ control diet vs. all other diets; $\mathrm{B}=18.5 \%$ DDGS diet vs. $10 \%$ CCDS diet; $\mathrm{C}=10 \%$ CCDS diet vs. $20 \%$ CCDS diet; $\mathrm{D}=20 \%$ CCDS diet vs. $18.5 \%$ DDGS $+10 \%$ CCDS diet.

${ }^{2} \mathrm{FE}=$ feed efficiency ( $\mathrm{kg}$ of ECM/kg of DMI). 
relative to the control when cows were fed 8 and $16 \%$ CCDS.

Milk protein and lactose percentages and yields were similar for all diets, which agreed with results of Udedibie and Chase (1988). Cows fed the control diet had greater $(P<0.01)$ MUN concentrations than cows fed distillers byproducts with values for all diets within a normal range. Distillers byproducts for which data are available have greater RUP content than many feeds (Schingoethe, 2007), which may lead to decreased production of ammonia in the rumen and consequently a reduction in MUN. Admittedly, RUP data for CCDS are lacking. Blood urea nitrogen was also greater $(P<$ 0.05 ) for cows fed the control diet. Baker et al. (1995) reported that cows fed excess dietary protein have increased concentrations of urea in the blood and milk.

Body weights $($ mean $=656 \mathrm{~kg})$ and BCS $($ mean $=3.39)$ were similar for all diets, although BCS was greater $(P<0.04)$ for the $10 \%$ CCDS diet than for the $18.5 \%$ DDGS diet.

\section{Milk Fatty Acids}

The fatty acid profile of milk fat is shown in Table 5 . Concentrations of the short- and medium-chain fatty acids that are synthesized in the mammary gland (i.e., C6:0 to C16:0) were greater, whereas the concentrations of cis-9 C18:1; trans-11 C18:1; cis-9, trans-11 CLA; and trans-10, cis-12 CLA were lower in milk from cows fed the control diet compared with all other diets. Da Cruz et al. (2005) observed that C12:0, C14:0, and C16:0 were greater for the control when compared with both added CCDS diets.

The concentration of C12:0 in milk was greater for the $10 \%$ CCDS diet compared with the $18.5 \%$ DDGS diet, whereas milk from cows fed the $20 \%$ CCDS diet had a lower concentration of $\mathrm{C} 16: 0$ than that from the $10 \%$ CCDS diet. Some of the short-chain fatty acids (C6:0, C8:0, C10:0, and C12:0) were lower in milk from cows fed the mixed diet (18.5\% DDGS + 10\% CCDS) compared with the $20 \%$ CCDS diet. Concentrations of cis-9 C18:1 and trans-11 C18:1 were greater for $20 \%$ CCDS compared with $10 \%$ CCDS and the other diets. Cis-9, trans-11 CLA was greater $(P<0.01)$ for $20 \%$ CCDS compared with $10 \%$ CCDS and was greater $(P<$ 0.01 ) when fed the mixed diet than when fed the $20 \%$ CCDS diet. Concentration of trans-10, cis-12 CLA was also greater $(P=0.01)$ for all other diets compared with the control. Several studies as reviewed by Bauman et al. (2006) indicated that trans-10, cis-12 CLA increases during diet-induced milk fat depression; however, in this study, milk fat content was similar with all diets (Table 4).
Concentrations of long-chain fatty acids were lower and medium-chain fatty acid concentrations were greater for cows fed the control diet when compared with all other diet groups. These data are consistent with a depression of de novo synthesis in the mammary gland that is compensated for by increased availability of long-chain fatty acids from increased dietary fat (Markus et al., 1996). Analogous to the report of $\mathrm{Da}$ Cruz et al. (2005), the observed long-chain fatty acid concentrations were greater for 20\% CCDS compared with $10 \%$ CCDS, whereas medium-chain fatty acids were greater when fed 10\% CCDS. The concentration of polyunsaturated fatty acids was greater for the DDGScontaining diets compared with the $10 \%$ CCDS diet. Unsaturated fatty acid concentrations in milk fat were greater for the CCDS diets compared with the control. The CLA desaturase index, as indicated by the ratio of cis-9, trans-11 CLA to trans-11 C18:1 (vaccenic acid), which gave an indication of the conversion between these 2 key fatty acids, was similar for all dietary comparisons.

Several studies (Palmquist and Jenkins, 1980; Elliott et al., 1993) demonstrated the importance of altering the milk fat composition by feeding, because about 40 to $45 \%$ of milk fatty acids are passed from the diet to milk fat unchanged. Increasing the intake of long-chain fatty acids by addition of feedstuffs rich in these fatty acids may improve the metabolic efficiency for increased milk production. In this study, the long-chain fatty acids, including the polyunsaturated fatty acids, were greater with the 20\% CCDS and 18.5\% DDGS diets. This implied that CCDS and DDGS diets were comparable with respect to increasing the polyunsaturated fatty acid and CLA contents in bovine milk. Although these fatty acids were increased in milk fat, calculated transfer efficiencies of dietary polyunsaturated fatty acids to milk fat were similar for all diets. $\mathrm{Hu}$ and Willett (2002) reported that consumption of milk rich in polyunsaturated fatty acids reduced cardiovascular disease in humans.

\section{Rumen Fluid Analysis}

Ammonia concentration in the rumen (Table 6) was greater $(P<0.05)$ when cows were fed the $20 \%$ CCDS diet compared with the 10\% CCDS diet. Cows fed the control diet had greater $(P<0.01)$ molar percentages of acetate and lower concentrations of propionate compared with other diets. A decrease in the ratio of propionate (glucogenic) to acetate and butyrate (lipogenic) in ruminal VFA can be related to a decreased production of liver glucose, glucose supply to the mammary gland, and lactose and milk synthesis in high-yielding dairy cows. 
Table 5. Milk fatty acid composition for cows fed control, 18.5\% dried distillers grains with solubles (DDGS), $10 \%$ condensed corn distillers solubles (CCDS), 20\% CCDS, and 18.5\% DDGS with 10\% CCDS treatment diets

\begin{tabular}{|c|c|c|c|c|c|c|c|c|c|c|}
\hline \multirow[b]{3}{*}{ Fatty acid } & \multicolumn{5}{|c|}{ Diet } & \multirow[b]{3}{*}{ SEM } & \multirow{2}{*}{\multicolumn{4}{|c|}{ Contrast $^{1}(P$-value $)$}} \\
\hline & \multirow[b]{2}{*}{ Control } & \multirow{2}{*}{$\begin{array}{l}18.5 \% \\
\text { DDGS }\end{array}$} & \multirow{2}{*}{$\begin{array}{l}10 \% \\
\text { CCDS }\end{array}$} & \multirow{2}{*}{$\begin{array}{l}20 \% \\
\text { CCDS }\end{array}$} & \multirow{2}{*}{$\begin{array}{l}18.5 \% \text { DDGS } \\
+10 \% \text { CCDS }\end{array}$} & & & & & \\
\hline & & & & & & & A & B & $\mathrm{C}$ & $\mathrm{D}$ \\
\hline & 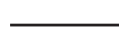 & $-(\mathrm{g} / 1 \mathrm{c}$ & $0 \mathrm{~g}$ of $\mathrm{f}$ & tty acid & & & & & & \\
\hline $\mathrm{C} 4: 0$ & 3.47 & 3.57 & 3.44 & 3.60 & 3.45 & 0.15 & 0.73 & 0.42 & 0.33 & 0.36 \\
\hline C6:0 & 1.99 & 1.85 & 1.90 & 1.87 & 1.67 & 0.08 & 0.05 & 0.65 & 0.77 & 0.05 \\
\hline C8:0 & 1.30 & 1.13 & 1.20 & 1.11 & 0.97 & 0.05 & $<0.01$ & 0.26 & 0.21 & 0.05 \\
\hline C10:0 & 3.09 & 2.52 & 2.72 & 2.43 & 2.08 & 0.12 & $<0.01$ & 0.20 & 0.07 & 0.05 \\
\hline C12:0 & 3.80 & 2.77 & 3.32 & 2.94 & 2.50 & 0.16 & $<0.01$ & 0.01 & 0.09 & 0.05 \\
\hline C14:0 & 11.74 & 10.10 & 10.65 & 10.40 & 8.89 & 0.37 & $<0.01$ & 0.25 & 0.60 & 0.01 \\
\hline C16:0 & 30.44 & 26.33 & 27.43 & 24.76 & 24.75 & 0.97 & $<0.01$ & 0.40 & 0.05 & 0.99 \\
\hline C16:1 & 1.20 & 1.11 & 1.15 & 1.26 & 1.05 & 0.10 & 0.49 & 0.66 & 0.29 & 0.05 \\
\hline C18:0 & 9.56 & 10.59 & 10.14 & 9.97 & 11.40 & 0.63 & 0.14 & 0.59 & 0.84 & 0.08 \\
\hline C18:1(cis-9) & 18.60 & 21.26 & 20.65 & 22.71 & 23.06 & 0.73 & $<0.01$ & 0.54 & 0.05 & 0.73 \\
\hline C18:1(trans-11) & 1.14 & 2.11 & 1.70 & 2.88 & 3.48 & 0.24 & $<0.01$ & 0.13 & $<0.01$ & 0.05 \\
\hline C18:1(trans-10) & 0.58 & 1.54 & 1.01 & 1.47 & 1.61 & 0.23 & $<0.01$ & 0.06 & 0.10 & 0.62 \\
\hline Other C18:1 & 0.23 & 0.36 & 0.32 & 0.39 & 0.39 & 0.02 & $<0.01$ & 0.19 & 0.05 & 0.97 \\
\hline $\mathrm{C} 18: 2($ trans $-9,12)$ & 1.44 & 1.48 & 1.98 & 1.29 & 1.33 & 0.17 & 0.66 & 0.05 & $<0.01$ & 0.89 \\
\hline C18:2(cis-9,12) & 2.86 & 3.90 & 2.72 & 2.72 & 3.57 & 0.12 & $<0.01$ & $<0.01$ & 0.99 & $<0.01$ \\
\hline CLA(cis-9,trans-11) & 0.33 & 0.68 & 0.51 & 0.85 & 1.07 & 0.06 & $<0.01$ & 0.05 & $<0.01$ & $<0.01$ \\
\hline CLA(trans-10,cis-12) & $<0.01$ & 0.01 & $<0.01$ & 0.02 & 0.02 & $<0.01$ & 0.01 & 0.26 & 0.49 & 0.60 \\
\hline $\mathrm{C} 18: 3 \alpha$ & 0.46 & 0.37 & 0.43 & 0.46 & 0.32 & 0.04 & 0.13 & 0.31 & 0.70 & 0.05 \\
\hline $\mathrm{C} 20: 0$ & 0.67 & 0.71 & 0.88 & 1.39 & 1.05 & 0.29 & 0.30 & 0.67 & 0.24 & 0.42 \\
\hline $\mathrm{C} 20: 3$ & 0.18 & 0.43 & 0.26 & 0.49 & 0.37 & 0.11 & 0.09 & 0.28 & 0.14 & 0.41 \\
\hline $\mathrm{C} 22: 3$ & 0.15 & 0.25 & 0.15 & 0.18 & 0.23 & 0.04 & 0.27 & 0.13 & 0.59 & 0.43 \\
\hline Others $^{2}$ & 6.79 & 7.96 & 7.88 & 7.75 & 7.86 & 0.46 & $<0.01$ & 0.87 & 0.79 & 0.82 \\
\hline Groupings of $\mathrm{FA}^{3}$ & & & & & & & & & & \\
\hline SCFA & 7.29 & 6.97 & 7.21 & 7.06 & 6.52 & 0.28 & 0.20 & 0.49 & 0.67 & 0.11 \\
\hline MCFA & 53.68 & 46.07 & 48.89 & 44.84 & 42.28 & 1.11 & $<0.01$ & 0.07 & 0.01 & 0.10 \\
\hline LCFA & 37.68 & 45.11 & 42.35 & 46.22 & 49.37 & 1.16 & $<0.01$ & 0.09 & $<0.05$ & 0.05 \\
\hline SFA & 68.54 & 61.75 & 64.20 & 60.64 & 58.77 & 1.02 & $<0.01$ & 0.07 & 0.01 & 0.16 \\
\hline MUFA & 24.81 & 29.73 & 28.41 & 31.97 & 32.88 & 0.93 & $<0.01$ & 0.28 & $<0.01$ & 0.45 \\
\hline PUFA & 5.18 & 6.55 & 5.71 & 5.42 & 6.41 & 0.19 & $<0.01$ & $<0.01$ & 0.23 & $<0.01$ \\
\hline CLA DS index ${ }^{4}$ & 0.28 & 0.34 & 0.29 & 0.31 & 0.31 & 0.02 & 0.21 & 0.11 & 0.43 & 0.99 \\
\hline
\end{tabular}

${ }^{1}$ Contrast: $\mathrm{A}=$ control diet vs. all other diets; $\mathrm{B}=18.5 \%$ DDGS diet vs. $10 \%$ CCDS diet; $\mathrm{C}=10 \%$ CCDS diet vs. $20 \%$ CCDS diet; $\mathrm{D}=20 \%$ CCDS diet vs. $18.5 \%$ DDGS $+10 \%$ CCDS diet.

${ }^{2}$ Others = sum of C5:0, C7:0, C11:0, C11:1, C12:1, C14:1t, C14:1c, C15:0, C16:1t, C17:0, C18:1t6, C18:1t9, C18:1c6, C19:0, C20:2, C22:0, C22:1, C20:5, C24:0, C24:1, C22:4, C22:5n-6, C22:5n-3, C22:n-6.

${ }^{3} \mathrm{SCFA}=$ short-chain fatty acids (C4:0 to $\left.\mathrm{C} 8: 0\right)$; MCFA = medium-chain fatty acids (C10:0 to C16:1); LCFA = long-chain fatty acids (C17:0 and above); SFA = saturated fatty acids; MUFA = monounsaturated fatty acids; PUFA = polyunsaturated fatty acids.

${ }^{4}$ CLA desaturase index $=($ CLA cis- -9, trans-11/C18:1 trans -11$)$.

Ruminal acetate concentrations when fed the CCDS diets were similar to the results of Da Cruz et al. (2005) and Gilbery et al. (2006), whereas Udedibie and Chase (1988) reported a greater acetate concentration for CCDS diets than for the control diet. Less acetate production in the rumen when feeding CCDS diets might have resulted from inhibition of fiber digestion caused by the high concentration of long-chain unsaturated fatty acids in those diets possibly coating feed particles or being toxic to fiber-digesting bacteria (Palmquist and Jenkins, 1980). Bateman and Jenkins (1998) reported that addition of soybean oil to the diets decreased the molar proportions of acetate and increased the molar proportions of propionate.

The concentration of butyrate was greater for the CCDS diets compared with the control and $18.5 \%$
DDGS diets, which reflected primarily a decrease in molar proportions of acetate. The concentration of isovalerate in ruminal fluid was greater for the control diet, possibly indicating more precursors for branchedchain fatty acids in the control diet (Johnson et al., 1994).

\section{CONCLUSIONS}

Results from this study indicate that CCDS can be incorporated into dairy cattle diets at greater concentrations (20\%) of diet DM, as long as the final diet does not contain more than $7 \%$ fat, without adversely affecting milk production or feed intake. Yields and composition of all major milk components were similar for all diets. Concentrations of long-chain fatty acids in 
Table 6. Ruminal ammonia and VFA concentrations for cows fed control, and diets containing 18.5\% dried distillers grains with solubles (DDGS), 10\% condensed corn distillers solubles (CCDS), 20\% CCDS, and a mixed diet containing $18.5 \%$ DDGS with $10 \%$ CCDS

\begin{tabular}{|c|c|c|c|c|c|c|c|c|c|c|}
\hline \multirow[b]{3}{*}{ Item } & \multicolumn{5}{|c|}{ Diet } & \multirow[b]{3}{*}{ SEM } & \multirow{2}{*}{\multicolumn{4}{|c|}{ Contrast $^{1}$ ( $P$-value $)$}} \\
\hline & \multirow[b]{2}{*}{ Control } & \multirow{2}{*}{$\begin{array}{l}18.5 \% \\
\text { DDGS }\end{array}$} & \multirow{2}{*}{$\begin{array}{c}10 \% \\
\text { CCDS }\end{array}$} & \multirow{2}{*}{$\begin{array}{l}20 \% \\
\text { CCDS }\end{array}$} & \multirow{2}{*}{$\begin{array}{l}18.5 \% \text { DDGS } \\
+10 \% \text { CCDS }\end{array}$} & & & & & \\
\hline & & & & & & & A & B & $\mathrm{C}$ & $\mathrm{D}$ \\
\hline $\mathrm{NH}_{3}, \mathrm{mg} / \mathrm{dL}$ & 5.67 & 4.78 & 5.34 & 8.75 & 6.13 & 1.23 & 0.61 & 0.70 & $<0.05$ & 0.07 \\
\hline Total VFA, mmol & 43.76 & 42.95 & 41.21 & 53.06 & 43.45 & 4.49 & 0.77 & 0.79 & 0.08 & 0.10 \\
\hline & & & $\mathrm{mol} / 10$ & $\mathrm{mmol})$ & & & & & & \\
\hline Acetate & 65.64 & 64.64 & 62.63 & 61.13 & 61.41 & 0.97 & $<0.01$ & 0.07 & 0.18 & 0.81 \\
\hline Propionate & 19.99 & 22.04 & 22.06 & 22.29 & 22.64 & 0.95 & $<0.01$ & 0.98 & 0.83 & 0.75 \\
\hline Isobutyrate & 1.05 & 0.91 & 0.99 & 0.93 & 0.86 & 0.04 & $<0.01$ & 0.08 & 0.16 & 0.18 \\
\hline Butyrate & 10.71 & 9.82 & 11.26 & 12.69 & 12.28 & 0.40 & 0.07 & $\leq 0.01$ & $\leq 0.01$ & 0.47 \\
\hline Isovalerate & 1.46 & 1.13 & 0.28 & 1.05 & 0.97 & 0.07 & $<0.01$ & 0.10 & 0.01 & 0.41 \\
\hline Valerate & 1.42 & 1.51 & 1.76 & 1.92 & 1.85 & 0.09 & $<0.01$ & 0.03 & 0.15 & 0.54 \\
\hline Acetate:propionate & 3.37 & 3.14 & 2.96 & 2.78 & 2.76 & 0.20 & $<0.01$ & 0.34 & 0.36 & 0.90 \\
\hline
\end{tabular}

${ }^{1}$ Contrast: $\mathrm{A}=$ control diet vs. all other diets; $\mathrm{B}=18.5 \%$ DDGS diet vs. $10 \%$ CCDS diet; $\mathrm{C}=10 \% \mathrm{CCDS}$ diet vs. $20 \%$ CCDS diet; $\mathrm{D}=20 \%$ CCDS diet vs. $18.5 \%$ DDGS + 10\% CCDS diet.

milk fat, including cis-9, trans-11 CLA, were greater for all distillers product diets compared with the control diet. The feeding of CCDS in place of DDGS is feasible due to the lower cost per kilogram (DM) of CCDS compared with DDGS. A practical concern with feeding more than $10 \%$ CCDS is the high $\mathrm{P}$ content of such diets, which may contribute to environmental pollution.

\section{ACKNOWLEDGMENTS}

The authors gratefully thank the farm crew at the South Dakota State University Dairy Research Unit (D. D. Rennich, manager) for care of the cows and assistance with data collection. The authors also wish to acknowledge partial financial support by the South Dakota Corn Utilization Council (Sioux Falls, SD) and supply of CCDS by Poet Nutrition (Sioux Falls, SD).

\section{REFERENCES}

AbuGhazaleh, A. A., D. J. Schingoethe, A. R. Hippen, and L. A. Whitlock. 2002. Feeding fish meal and extruded soybeans enhances the conjugated linoleic acid (CLA) content of milk. J. Dairy Sci. 85:624-631.

Anderson, J. L., D. J. Schingoethe, K. F. Kalscheur, and A. R. Hippen. 2006. Evaluation of dried and wet distillers grains included at two concentrations in the diets of lactating dairy cows. J. Dairy Sci. 89:3133-3142

AOAC. 2002. Official Methods of Analysis. 18th ed. Association of Official Analytical Chemists, Gaithersburg, MD.

Baker, L. D., J. D. Ferguson, and W. Chalupa. 1995. Responses in urea and true protein to different feeding schemes for dairy cows. J. Dairy Sci. 78:2424-2434.

Bateman, H. G., II, and T. C. Jenkins. 1998. Influence of soybean oil in high fiber diets fed to nonlactating cows on ruminal unsaturated fatty acids and nutrient digestibility. J. Dairy Sci. $81: 2451-2458$.

Bauman, D. E., I. H. Mather, R. J. Wall, and A. L. Lock. 2006. Major advances associated with the biosynthesis of milk. J. Dairy Sci. 89:1235-1243.
Belyea, R., S. Eckhoff, M. Wallig, and M. Tumbleson. 1998. Variability in the nutritional quality of distillers solubles. Bioresour. Technol. 66:207-212.

Chaney, A. L., and E. P. Marbach. 1962. Modified reagents for determination of urea and ammonia. Clin. Chem. 8:130-132.

Da Cruz, C. R., M. J. Brouk, and D. J. Schingoethe. 2005. Lactational response of cows fed condensed corn distillers solubles. J. Dairy Sci. 88:4000-4006.

Elliott, J. P., J. K. Drackley, D. J. Schauff, and E. H. Jaster. 1993. Diets containing high oil corn and tallow for dairy cows during early lactation. J. Dairy Sci. 76:775-789.

Feron, W. R. 1939. The carbamido diacetyl reaction: A test for citrulline. Biochem. J. 33:902-907.

Gilbery, T. C., G. P. Lardy, S. A. Soto-Navarro, M. L. Bauer, and J. S. Caton. 2006. Effects of corn condensed distillers solubles supplementation on ruminal fermentation, digestion, and in situ disappearance in steers consuming low-quality hays. J. Anim. Sci. 84:1468-1480.

Grant, R. J. 1997. Interactions among forages and nonforage fiber sources. J. Dairy Sci. 80:1438-1446.

Hu, F. B., and W. C. Willett. 2002. Optimal diets for prevention of coronary heart disease. JAMA 288:2569-2578.

Huhtanen, P., and H. Miettinen. 1992. Milk production and concentrations of blood metabolites as influenced by the level of wet distillers solubles in dairy cows receiving grass silage-based diet. Agric. Sci. Finl. 1:279-290.

Johnson, T. R., M. J. Cecava, E. B. Sheiss, and K. D. Cunningham. 1994. Addition of ruminally degradable crude protein and branched-chain volatile fatty acids to diets containing hydrolyzed feather meal and blood meal for lactating cows. J. Dairy Sci. 77:3676-3682.

Kleinschmit, D. H., D. J. Schingoethe, K. F. Kalscheur, and A. R. Hippen. 2006. Evaluation of various sources of corn dried distillers grains plus solubles for lactating dairy cattle. J. Dairy Sci. 89:4784-4794.

Lahr, D. A., D. E. Otterby, D. G. Johnson, J. G. Linn, and R. G. Lundquist. 1983. Effects of moisture content of complete diets on feed intake and milk production by cows. J. Dairy Sci. 66:1891-1900.

Leonardi, C., S. Bertics, and L. E. Armentano. 2005. Effect of increasing oil from distillers grains or corn oil on lactation performance. J. Dairy Sci. 88:2820-2827.

Lowry, J. B., L. L. Conlan, A. A. Schlink, and C. S. McSweeny. 1994. Acid detergent dispersible lignin in tropical grasses. J. Food Agric. 65:41-50.

Maiga, H. A., D. J. Schingoethe, and F. C. Ludens. 1995. Evaluation of diets containing supplemental fat with different sources of 
carbohydrates for lactating dairy cows. J. Dairy Sci. 78:11221130 .

Markus, S. B., K. M. Wittenberg, J. R. Ingalls, and M. Undi. 1996. Production responses by early lactation cows to whole sunflower seed or tallow supplementation of a diet based on barley. J. Dairy Sci. 79:1817-1825.

NRC. 2001. Nutrient Requirements of Dairy Cattle. 7th rev. ed. Natl. Acad. Sci., Washington, DC.

Orth, R. 1992. Sample day and lactation report. DHIA 200 Fact Sheet A-2. Mid-States DRPC, Ames, IA.

Ottenstein, D. M., and D. A. Bartley. 1971. Separation of free acids C2 - C5 in dilute aqueous solution column technology. J. Chromatogr. Sci. 9:673-681.

Palmquist, D. L., and T. C. Jenkins. 1980. Fat in lactation rations: Review. J. Dairy Sci. 63:1-14.

Robertson, J. B., and P. J. Van Soest. 1981. The detergent system of analysis and its application to human foods. Pages 123-158 in The Analysis of Dietary Fiber in Food. W. P. T. James and O. Theander, ed. Marcel Dekker Inc., New York, NY.

SAS Institute. 1999. SAS User's Guide: Statistics. Version 8.01 ed. SAS Institute Inc., Cary, NC.

Schingoethe, D. J. 2007. Feeding corn distillers grains to dairy cattle. Pages 15-28 in Ontario Dairy Symposium for Large Herd Opera- tors, London, Ontario, Canada. Ontario Large Herd Operators, Elora, Ontario, Canada.

Schingoethe, D. J., M. J. Brouk, and C. P. Birkelo. 1999. Milk production and composition from cows fed wet corn distillers grains. J. Dairy Sci. 82:574-580.

Sukhija, P. S., and D. L. Palmquist. 1988. A rapid method for determination of total fatty acid content and composition of feedstuffs and feces. J. Agric. Food Chem. 36:1202.

Udedibie, A. B. I., and L. E. Chase. 1988. The value of corn condensed distillers solubles (CCDS) for milk production in dairy cows. Niger. Agric. J. 23:118-129.

Undersander, D., D. R. Mertens, and N. Thiex. 1993. Forage analysis procedures. National Forage Testing Association, Omaha, NE.

Van Soest, P. J., J. B. Robertson, and B. A. Lewis. 1991. Methods for dietary fiber, neutral detergent fiber, and nonstarch polysaccharides in relation to animal nutrition. J. Dairy Sci. 74:35833597.

Wildman, E. E., G. M. Jones, P. E. Wagner, R. L. Boman, H. F. Troutt, Jr., and T. N. Lesch. 1982. A dairy cow body condition scoring system and its relationship to standard production characteristics. J. Dairy Sci. 65:495-501.

Wybenga, D. R., J. D. Giorgio, and V. J. Pileggi. 1971. Manual and automated methods for urea nitrogen measurement in whole serum. Clin. Chem. 17:891-895. 